\title{
Pengaruh Motivasi dan Disiplin Kerja terhadap Kinerja Pegawai pada Badan Pengelola Pajak dan Restribusi Daerah Muaro Jambi
}

\author{
Endang Dofitria Angraini \\ Mahasiswa Fakultas Ekonomi Prodi Manajemen Sumber Daya Manusia Universitas Batanghari Jambi \\ Corresponding email: endangdofitria@gmail.com
}

\begin{abstract}
This reseach was to analyse how the effect of motivation and dicipline on job performance. How to as well as a condition of motivation, dicipline and job performance at the Tax Management and Restrition of Muaro Jambi Area.The research methodology is descriptive and quantitative analysis methods. Data used is secondary data.The population become object in this research is job performance at Tax Management and Restrition of Muaro Jambi Area. The method for analysis is analysis multifly regression, hypotesis test, correlation so determinant coefficient and $F_{-}$tes so t_test. The object of this research is the Tax Management and Restrition of Muaro Jambi Area. This office is a branch of Tax Management and Restrition of Muaro Jambi Area, which is the task of collect tax on earth and buildings and other taxes in the Muaro Jambi area.Analysis on the research of respondents felt a high motivation and work discipline in the performance of tasks provided by the superiors. In the statement of respondents the indicator comes and home work on time shows the hihest score, which is a score of 280 verry high categories. Multiple linear regression equations are $Y=8,266+0.243 X 1+0.740 X 2+E$. Independent variables (motivation and work discipline) simultaneously have significant effect on the dependent variables (performance of members). While partial motivation affects performance and variable work discipline affects of the performance. Conclusion that the motivation and discipline have significant effect on performance and have a positive relationship in Tax Management and Restrition of Muaro Jambi Area.
\end{abstract}

Keyword : motivation, dicipline, job performance.

\section{PENDAHULUAN}

Pesatnya perkembangan ekonomi global saat ini mengalami kemajuan yang sangat pesat. Dimana setiap negara dituntut untuk mengikuti kemajuan teknologi yang tiada batas antar negara satu dengan dengan negara lainnya. Hal ini berdampak juga dengan perkembangan kebutuhan tenaga kerja yang mendukung terhadap roda perekonomian suatu negara. Dimana tenaga kerja merupakan asset suatu organisasi yang dijadikan sumber daya pendorong untuk mewujudkan kepentingankepentingan perusahaan. Sumber daya manusia juga merupakan modal suatu organisasi baik organisasi pemerintahan maupun organisasi swasta, untuk mencapai tujuan atau target yang ingin dicapai. Manusia merupakan unsur terpenting dalam setiap organisasi dalam merealisasikan tujuan dari organisasi. Keberhasilan organisasi untuk mencapai tujuan dan sasarannya serta kamampuannya menghadapi berbagai tantangan, baik yang bersifat internal maupun yang bersifat eksternal ditentukan oleh kualitas sumber daya manusia.

Menyadari akan semakin pentingnya sumber daya manusia dalam suatu organisasi, maka pengelolaan sumber daya manusia perlu diperhatikan. Karena kunci sukses organisasi bukan hanya terbentuk pada tersedianya modal yang cukup dan keunggulan saja, tapi lebih dari itu sangat tergantung pada bagaimana mengelola sumber daya manusia. Pengelolaan sumber daya manusia sangat berkaitan manajemen sumber daya manusia. Menurut Handoko,(2015:15) mengemukakan bahwa : Manajemen sumberdaya manusia merupakan kegiatan yang mengatur tentang cara pengadaan tenaga kerja, melakukan pengembangan, memberikan kompensasi, pemeliharaan, dan pemisahan tenaga kerja melalui proses-proses manajemen dalam rangka mencapai tujuan organisasi. Manajemen sumberdaya manusia terdiri atas serangkaian keputusan yang terintegrasi tentang hubungan ketenagakerjaan yang mempengaruhi efektivitas pegawai dan organisasi. Sehingga pelaksanaan sumber daya manusia yang baik akan mendorong peningkatan kinerja pegawai suatu organisasi.

Sumber daya manusia yang dalam hal ini adalah para pegawai pada sebuah organisasi, tentunya berusaha bekerja dengan kemampuan yang mereka miliki agar dapat mencapai kinerja yang diinginkan organisasi tersebut. Rasa aman dan kenyamanan akan suasana kerja mampu mendorong pegawai untuk lebih berdedikasi tinggi dalam menyelesaikan pekerjaan, dan akan membantu pegawai mencapai kinerja yang terbaik. Yang mana kinerja merupakan suatu hasil kerja yang dicapai seseorang dalam melaksanakan tugas-tugas yang dibebankan kepadanya yang didasarkan atas kecakapan, pengalaman dan kesungguhan serta waktu. Peningkatan kinerja pegawai dalam suatu organisasi sangat diperlukan agar tujuan yang diinginkan oleh organisasi dapat direaliasikan dengan baik. Kinerja suatu organisasi akan meningkat apabila terdapat kerjasama dan hubungan yang baik antara pimpinan dan pegawainnya. Dengan meningkatkan kinerja pegawai akan meningkatkan kinerja perusahaan. Untuk itu 
pegawai sebaiknya diperlakukan sebagai partner kerja dan bukan sebagai pekerja semata.

Untuk mendapatkan kinerja pegawai sesuai dengan yang diharapkan, organisasi mempunyai tugas untuk memberikan dorongan kepada para pegawai, agar mereka bekerja dengan giatnya sehingga mencapai target organisasi. Secara teori berbagai definisi tentang motivasi biasanya terkandung keinginan, harapan, kebutuhan, tujuan, sasaran, dorongan dan insetif. Pegawai bekerja dengan harapan akan memperoleh upah/gaji yang dapat untuk memenuhi kebutuhan tersebut. Dorongan seseorang untuk bekerja dipengaruhi adanya kebutuhan yang harus dipenuhi dan tingkat kebutuhan yang berbeda pada setiap pegawai, sehingga dapat terjadi perbedaan motivasi dalam berprestasi. Selain itu, pemenuhan kebutuhan dari para pegawaian akan pelayanan dan penghargaan oleh atasan terhadap prestasi kerja yang dihasilkan yang sesuai dengan prinsip keadilan dapat memotivasi kerja mereka. Organisasi sendiri juga berperan dalam mengelola pegawai agar mematuhi segala peraturan, norma yang telah ditetapkan oleh organisasi sehingga para pegawai bekerja dengan disiplin dan efektif.

Berbagai aturan/norma yang ditetapkan oleh suatu organisasi memiliki peran yang sangat penting dalam menciptakan kedisiplinan agar para pegawai dapat mematuhi dan melaksanakan peraturan tersebut. Aturan atau norma tersebut biasanya diikuti oleh sanksi yang diberikan apabila adanya palanggaran. Sanksi tersebut bisa berupa teguran baik lisan maupun tulisan, skorsing, penurunan pangkat bahkan sampai pemecatan tergatung dari besarnya pelanggaran yang dilakukan oleh pegawai.

Disiplin kerja merupakan salah satu aspek dalam sistem kerja yang harus diperhatikan oleh sebuah organisasi atau perusahaan untuk meningkatkan kinerja atau produktivitas sebuah organisasi. Sehingga baik atau tidaknya disiplin kerja yang dimiliki pegawai tersebut dipengaruhi oleh baik atau tidaknya sistem pendisiplinan yang dijalankan oleh sebuah organisasi. Bila pegawai memiliki disiplin kerja yang tinggi, diharapkan akan mampu menyelesaikan tugas dengan cepat dan tepat sehingga kinerja yang dihasilkan akan baik.Namun, masih cukup banyak terjadi kesenjangan yang kurang sesuai dengan idealisme. Masih ada beberapa kelemahan yang masih ditunjukan oleh pegawai dimana mereka kurang termotivasi dengan pekerjaannya sehingga membuat mereka tidak menjadi pribadi yang disiplin. Ada yang datang tidak tepat waktu saat masuk kantor, menunda tugas kantor, kurang disiplin, tidak bisa memanfaatkan sarana kantor dengan baik dan masih adanya sebagian pegawai yang meninggalkan tugas pada jam kerja tanpa keterangan yang sah. Oleh karena itu perlu diberi aware kepada pegawai sehingga para pegawai termotivasi memberikan upaya yang terbaik dalam melaksanakan pekerjaan.
Menurut Mangkunegara,(2005:45) menyatakan motivasi terbentuk dari sikap (attitude) pegawai dalam menghadapi situasi kerja di organisasi (situation). Motivasi merupakan kondisi atau energi yang menggerakkan diri pegawai yang terarah atau tertuju untuk mencapai tujuan organisasi perusahaan. Sikap mental karyawan yang pro dan positif terhadap situasi kerja itulah yang memperkuat motivasi kerjanya untuk mencapai kinerja maksimal. Motivasi penting karena dengan motivasi ini diharapkan setiap individu karyawan mau bekerja keras dan antusias untuk mencapai produktivitas kerja yang tinggi. Pada penelitian ini, yang menjadi objek penelitian adalah pegawai tetap yang bekerja pada kantor Badan Pengelola Pajak dan Restribusi Daerah (BPPRD) Kabupaten Muaro Jambi. Badan Pengelola Pajak dan Restribusi Daerah (BPPRD) Kabupaten Muaro Jambi bertanggung jawab untuk urusan pendapatan daerah berdasarkan azas otonomi dan pembantuan. Selain itu Badan Pengelola Pajak Dan Restribusi Daerah Kabupaten Muaro Jambi mempunyai tugas utama yaitu sebagai penyelenggara untuk pemungutan pendapatan daerah wilayah kerjanya dan sebagai koordinator instansi lain dalam perencanaan, pelaksanaan, pengendalian hingga evaluasi pemungutan pendapatan daerah.

\section{METODE}

Metode yang dilakukan dalam penelitian ini adalah penelitian lapangan/ survey. Menurut Sugiyono (2010:12), metode penelitian survey merupakan penelitian yang mengambil sampel dari suatu populasi dan menggunakan kuisioner sebagai alat pengumpulan data dan informasi yang relavan dengan masalah penelitian. Populasi dalam penelitian ini adalah Pegawai Badan Pengelola Pajak dan Restribusi Daerah Kabupaten Muaro Jambi. Data yang digunakan adalah data primer. Data primer adalah data yang diperoleh atau dikumpulkan langsung di lapangan oleh orang yang melakukan penelitian atau yang bersangkutan memerlukannya. Data primer dalam penelitian ini dapat berupa kuisioner. Sumber data adalah subjek dari mana data dapat diperoleh. Adapun sumber data dalam penelitian ini berasal dari BPPRD Muaro Jambiyang didapat dari Bagian Tata Usaha.

Populasi adalah keseluruhan subjek penelitian. (Sunyoto 2013:42) Apabila seseorang ingin meneliti semua elemen yang ada dalam wilayah penelitian, maka penelitiannya merupakan penelitian populasi. Studi atau penelitiannya juga disebut studi populasi atau studi sensus (Arikunto 2010). Sedangkan sampel adalah sebagian atau wakil populasi yang diteliti (Sunyoto 2013:44). Dinamakan penelitian sampel apabila kita bermaksud untuk menggeneralisasikan hasil penelitian sampel. Yang dimaksud menggeneralisasikan adalah mengangkat kesimpulan penelitian sebagai suatu yang berlaku bagi populasi (Arikunto, 2010:38). Populasi 
dalam penelitian ini adalah seluruh pegawai pada BPPRD Muaro Jambi tahun 2019 sebanyak 50 orang yang merupakan populasi. Menurut Arikunto (2010:39)bahwa apabila jumlah populasi kurang dari 100 maka seluruhnya dijadikan sampel, apabila lebih dari 100 maka sampel dapat diambil dari 10\%, 15\%, 20\%, 50\% dan seterusnya dari jumlah populasi. Populasi karyawan yang berjumlah 50 orang dengan kata lain metode data sensus karena kurang dari 100 , maka penelitian ini mengambil subjek seluruhnya untuk diteliti.

Dalam penelitian ini, akan menganalisis data yang diperoleh secara deskriptif kualitatif. Analisis dilakukan berdasarkan teori yang mempunyai kaitan erat dengan aspek yang diteliti. Menurut Umar (2013:95) analisis deskriptif kualitatif adalah menyesuiakan keadaan sebenarnya dan menggambarkan karakteristik peristiwa yang diamati serta menyimpulkan secara benar dan menyeluruh berdasarkan metode ilmiah dan menggunakan teori-teori yang dipelajari dan konsep yang relevan dalam permasalahan sebagai landasan berpijak dalam menganalisis.Untuk menganalisis permasalahan diatas digunakan skala penelitian dengan menghitung frekuensi skor setiap item pertanyaan. Seperti yang dikemukakan Umar (2013:125) bahwa perhitungan skor setiap komponen yang diteliti dengan mengalikan seluruh frekuensi data dengan nilai bobot.

\section{Regresi Linier Berganda}

Untuk menjawab tujuan dan hipotesis penelitian digunakan analisis regresi linier berganda. Menurut Supardi (2013:110), rumus persamaan regresi linier berganda adalah sebagai berikut $: Y=a+b_{1} X_{1}+b_{2} X_{2}$ +e.Menurut Sugiyono (2010:113) uji F digunakan untuk menguji variabel-variabel bebas secara bersama-sama terhadap variabel regresi linier yang digunakan sudah tepat atau belum. Dan menurut Sugiyono (2010:112) uji t pada dasarnya menunjukkan seberapa jauh pengaruh suatu variabel penjelas secara individual dalam menerangkan variasi variabel terikat.

\section{HASIL DAN PEMBAHASAN}

Analisis data merupakan output dari hasil pengolahan data yang diimplementasikan pada rumusan masalah yang ada pada penelitian. Pada pokok bahasan ini ada beberapa yang akan disajikan yakni : uji kualitas data, uji asumsi klasik dan uji hipotesis.

\section{Uji Kualitas Data}

Data penelitian tidak bermanfaat apabila instrumen yang digunakan untuk mengumpulkan data penelitian tidak memiliki reliabilitas dan validitas yang tinggi (Supandi,2013:89). Uji Kualitas data dilakukan menggunakan uji validitas dengan korelasi pearson dan uji realibilitas dengan cronbach alpha

\section{Uji Validitas}

Uji validasi untuk mengetahui apakah alat ukur dari variabel yang diingikan sesuai atau tidak. Dikatakan pengujian terhadap alat ukur yang dipakai untuk mengetahui validasi variabel yang digunakan dalam penelitian ini menggunakan korelasi product moment dengan bantuan program SPSS 22.00. Suatu item pertanyaan dinyatakan valid jika nilai koefisien korelasi ( $\mathrm{r}_{\text {hitung }}$ ) melebihi nilai $\mathrm{r}_{\text {tabel }}$ pada tingkat signifikasi $5 \%$ dan $\mathrm{N}=50$ yaitu sebesar 0,2306. Berdasarkan hasil perhitungan dengan menggunakan software SPSS 22.00 diperoleh $\mathrm{r}_{\text {hitung }}$ sebagai berikut :

Tabel 1. Validitas

\begin{tabular}{llrrr}
\hline & & Motivasi & Disiplin & Kinerja \\
\hline Motivasi & Pearson Correlation & 1 &, 455 &, 598 \\
& Sig. (2-tailed) & &, 000 &, 000 \\
& $\mathrm{~N}$ & 50 & 50 & 50 \\
Disiplin & Pearson Correlation &, 455 & 1 &, $593^{* *}$ \\
& Sig. (2-tailed) &, 000 & &, 000 \\
& N & 50 & 50 & 50 \\
Kinerja & Pearson Correlation &, 598 &, $593^{* *}$ & 1 \\
& Sig. (2-tailed) &, 000 &, 000 & \\
& N & 50 & 50 & 50 \\
\hline
\end{tabular}

Dari tabel 1, maka terlihat bahwa motivasi dan disiplin $\mathrm{r}_{\text {hitung }}$ (pearson correlation) dengan menggunakan SPSS 22 lebih besar dari $r_{\text {tabel }}\left(r_{\text {hitung }}>\right.$ $\left.r_{\text {tabel }}\right)$ atau $0,598>0,2306$ dan 0,593>0,2306, ini memberi makna bahwa semua data dari variabel dependent (motivasi dan disiplin) maupun variabel independen (kinerja) dapat digunakan untuk penelitian atau semua data valid.

\section{Uji Reliabilitas}

Reliabilitas adalah sejauh mana hasil suatu pengukuran dapat dipercaya. Implikasinya hasil pengukuran dapat dipercaya apabila dalam beberapa kali pengukuran terhadap kelompok/subjek yang sama diperoleh hasil yang relatif sama. Dalam penelitian ini reliabilitas ditafsirkan dengan menggunakan koefisien Alpha Croncbach $(\alpha)$. Suatu variabel dikatakan reliabel jika nilai koefisien alphanya lebih dari 0,2306.Hasil perhitungan nilai alpha diperoleh sebagai berikut :

Tabel 2. Uji Reliabilitas

\begin{tabular}{cc}
\hline Cronbach's Alpha & N of Items \\
, 612 & 3 \\
\hline
\end{tabular}

Menurut Supandi (2013:98) suatu instrumen dinyatakan reliabel bila nilai alphanya lebih besar dari nilai $r_{\text {tabel. }}$ Dari tabel 4.13 bahwa instrumen memiliki nilai Cronbach's alpha lebih besar dari nilai $\mathrm{r}_{\text {tabel }}(0,612$ $>$ 0,2306) sehingga disimpulkan bahwa instrumen penelitian adalah reliabel atau layak untuk dijadikan data 


\section{Uji Asumsi Klasik}

Uji ini digunakan untuk mengetahui apakah model dari regresi linier berganda yang digunakan untuk menganalisa dalam penelitian ini terbatas dari penyimpangan atau tidak. Menurut Sunjoyo (2013:59), asumsi klasik yang meliputi Uji Normalitas, Multikolenaritas, Autokorelasi, dan Heterokedasitas. Adapun masing-masing pengujian terbatas dapat dijelaskan sebagai berikut:

\section{Uji Normalitas}

Uji Normalitas digunakan untuk menguji apakah model regresi, variabsel dependent dan variabel independen mempunyai distribusi normal atau tidak. Untuk mendeteksi normalitas dapat dilakukan dengan uji statistik. Test statistik yang digunakan adalah normal probability plots.

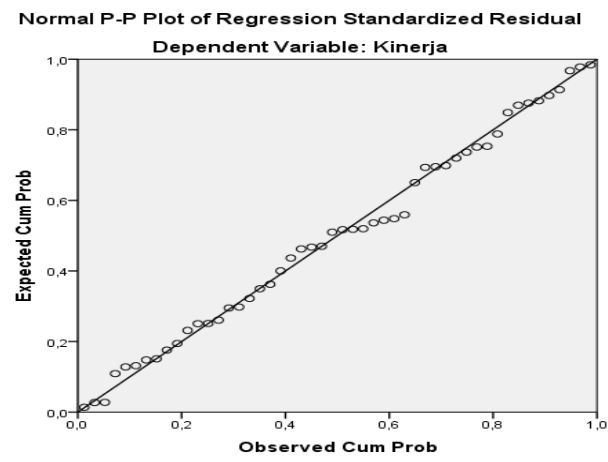

Gambar 1. Normalitas

Berdasarkan Gambar 1 grafik normal probability plot dapat diketahui bahwa sebaran titik-titik data residual disekitar mendekati garis diagonal, maka dapat diartikan bahwa data yang diteliti berdistribusi normal. (Sunyoto,2013:65)

\section{Uji Multikolineritas}

Uji ini digunakan untuk mengetahui apakah terdapat korelasi diantara variabel-variabel independen dalam model regresi tersebut. Untuk mendeteksi ada tidaknya multikolineritas dalam model regresi dapat dilihat dari tolenrace value atau variance inflation factor (VIF), dengan ketentuan sebagai berikut : (Sunyoto,2013:90) Jika nilai tolerance $>0,10$ dan nilai VIF < 10, maka dapat di simpulkan bahwa tidak ada multikolineritas antar variabel independen dalam model regresi. Jika nilai tolenrance $<0,10$ dan nilai VIF $>10$, maka dapat di simpulkan bahwa ada multikolineritas antara variabel independen dalam model regresi.

Tabel 3. Multikolineritas

\begin{tabular}{lcc}
\hline Model & \multicolumn{2}{c}{ Collinearity Statistics } \\
\cline { 2 - 3 } & Tolerance & VIF \\
Motivasi &, 587 & 1,563 \\
Disiplin &, 997 & 1,003 \\
\hline
\end{tabular}

Berdasarkan hasil hitungan yang ada pada Tabel 3 maka dapat diketahui tolerance Motivasi dan Disiplin Kerjalebih besar dari 0,10 (10\%). sedangkan VIF dari nilai Motivasi dan Disiplin Kerja lebih kecil dari 10. Maka dapat dikatakan bahwa data residualnya tidak mempunyai gejala multikolineritas.

\section{Uji Autokorelasi}

Uji Autokorelasi bertujuan untuk menguji apakah model regresi linier ada korelasi antara kesalahan penganggu pada periode $\mathrm{t}$ dengan kesalahan pengguna pada periode t-1 (sebelumnya). Jika terjadi korelasi, maka ada masalah autokorelasi. Untuk mendeteksi autokorelasi, dapat dilakukan uji statistik melalui Durbin-Waston (DW test). Dengan ketentuan sebagai berikut : (Prayitno,2012:125)Terjadi autokorelasi positif, jika nilai DW dibawah -2 ( DW $<-2$ ). Tidak terjadi autokorelasi, jika nilai DW berada antara -2 dan +2 atau $-2<\mathrm{DW}<+2$. Terjadi autokorelasi negatif jika nilai DW diatas +2 atau $\mathrm{DW}>+2$.

Tabel 4. Hasil Uji Autokorelasi

\begin{tabular}{|c|c|c|c|c|c|}
\hline Model & $\mathrm{R}$ & R Square & Adjusted R Square & Std. Error of the Estimate & Durbin-Watson \\
\hline 1 &, $837^{\mathrm{a}}$ & ,705 &, 680 & 3,44156 & 1,358 \\
\hline
\end{tabular}

Berdasarkan hasil hitungan yang ada pada tabel 4.16 dapat diketahui nilai Durbin Watson sebesar 1,358, sehingga nilai DW berada diantara -2 sampai +2 berarti bahwa data residual tidak terjadi autokorelasi positif maupun negatif.

\section{Uji Heterokedasitas}

Uji ini bertujuan untuk menguji apakah dalam model regresi terjadi ketidaksamaan variance dari residual satu pengamatan ke pengamatan lain. Untuk mendeteksi adanya Heterokedasitas dilakukan dengan melihat grafik plot antara nilai prediksi variabel terkait (ZPRED) dengan residulnya (SRESID). Dengan ketentuan sebagai berikut:Jika ada pola tertentu, seperti titik-titik yang membentuk suatu pola tertentu, yang teratur (bergelombang, melebar, kemudian menyempit), maka terjadi mengindikasikan telah terjadi heterokedasitas.Jika tidak ada pola tertentu serta titiktitik menyebar diatas dan dibawah angka nol pada sumbu Y,maka tidak terjadi heteroskidasitas, maka mengidentifikasikan telah terjadi heteroskidasitas. 


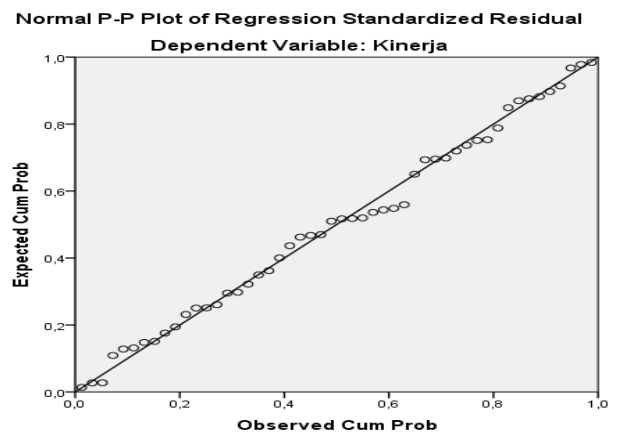

Gambar 2. Uji Heteroskedastisitas

Berdasarkan gambar 2 Scatterplot dapat diketahui bahwa titik- titik data residual menyebar secara acak, tidak membentuk suatu pola tertentu yang jelas dan tersebar baik di atas maupun di bawah angka 0 (nol) pada sumbu Y. Hal ini dapat disimpulkan bahwa regresi yang dihasilkan tidak terdapat gejala heteroskedastisitas. Dari uraian uji asumsi klasik maka data-data residual yang teliti memenuhi kriteria uji asumsi klasik. Maka data-data yang diteliti dapat dilanjutkan kedalam persamaan refresi linier berganda.

\section{Analisis Regresi Linier Berganda}

Persamaan regresi linier berganda dimaksudkan untuk melihat model yang bagaimana untuk keterpengaruh variabel independen terhadap variabel dependen. Dengan menggunakan sofware SPSS versi 22.0 diperoleh hasil perhitugannya pada tabel 5 sebagai berikut:

Tabel 5. Hasil Uji Regresi Berganda

\begin{tabular}{|c|c|c|c|c|c|c|}
\hline \multirow{2}{*}{\multicolumn{2}{|c|}{ Model }} & \multicolumn{2}{|c|}{ Unstandardized Coefficients } & Standardized Coefficients & \multirow[b]{2}{*}{$\mathrm{t}$} & \multirow[b]{2}{*}{ Sig. } \\
\hline & & B & Std. Error & Beta & & \\
\hline 1 & (Constant) & 8,266 & 3,766 & & 2,195 & ,033 \\
\hline & Motivasi & 243 & ,118 & ,232 & 2,056 & ,045 \\
\hline & Disiplin & ,740 & 138 & 606 & 5,377 & ,000 \\
\hline
\end{tabular}

Dari hasil perhitungan diperoleh data dari tabel 5 koefisien konstanta adalah sebesar 8,266, koefisein regresi motivasi sebesar 0,243 untuk koefisien regresi disiplin sebesar 0,740. Maka hubungan antara variabelvariabel independen dengan variabel dependen dalam model persamaan regresi linier berganda dapat diformulasikan dalam persamaan sebagai berikut: $\mathrm{Y}=$ $8,266+0,243 \mathrm{X}_{1}+0,740 \mathrm{X}_{2}+\mathrm{e}$

\section{Uji Hipotesis}

Untuk mengetahui apakah ada pengaruh variabel independen secara simultan terhadap variabel dependen digunakan uji anova atau F-test, sedangkan pengaruh masing-masing variabel independen secara parsial (sendiri-sendiri) diukur dengan menggunakan uji t- test. Uji F

Uji $F$ digunakan untuk menguji signifikan pengaruh variabel independen secara simultan (bersama-sama) dalam menerangkan variasi variabel dependen. Berikut ini merupakan hasil dari Uji-F yang dapat dilihat pada tabel 4.18 sebagai berikut:

Tabel 6. Anova

\begin{tabular}{llrrrrr}
\hline Model & & Sum of Squares & df & Mean Square & F & Sig. \\
\hline 1 & Regression & 379,348 & 2 & 189,674 & 16,014 &, $000^{\mathrm{b}}$ \\
& Residual & 556,684 & 47 & 11,844 & \\
& Total & 936,031 & 49 & & \\
\end{tabular}

Dari hasil perhitungan menggunakan program SPSS 22, maka pertama membandingkan $\mathrm{F}_{\text {hitung }}$ terhadap $\mathrm{F}_{\text {tabel }}$ dengan taraf signifikan $\alpha=0,05$ (5\%). Dari tabel 4.18 diketahui $F_{\text {hitung }}$ sebesar 16,014 dengan membandingkan $\mathrm{F}_{\text {tabel }} \alpha=0,05$ dengan derajat bebas pembilang 2 dan derajat bebas penyebut 47 , didapat $\mathrm{F}_{\text {tabel }}$ sebesar 3,20. $\mathrm{F}_{\text {hitung }}$ lebih besar dari $\mathrm{F}_{\text {tabel }}(16,014>$ 3,20 ). Bila dihubungkan dengan hipotesis terdahulu dapat memaknakan, Ho ditolak dan $\mathrm{Ha}$ diterima. Sedangkan untuk mendapatkan signifikan antar variabel independen dengan dependen, yakni dengan membandingkan sig dengan $\alpha$, sig $(0,000)<\alpha(0,05)$. Artinya variasi dari variabel independen signifikan dengan variabel dependen.

\section{Uji $t$}

Uji t digunakan untuk mengetahui apakah variabel independen secara parsial berpengaruh signifikan terhadap variabel dependen. Tingkat signifikan menggunakan $\alpha=5 \%$ (signifikansi 0,05 adalah ukuran standar yang sering digunakan dalam penelitian). Menentukan $t_{\text {hitung }}$ dengan menggunakan tingkat keyakinan 95\%, derajat kebebasan (df) n-k-1 atau $50-2-1=47$. Maka $\mathrm{t}_{\text {tabel }}(\alpha=0,05$, df $=47)$ diperoleh sebesar 1,678.

Dari hasil analisis regresi output coefficients dapat diketahui thitung dalam tabel 6 sebagai berikut : 
Endang Dofitria Angraini, Pengaruh Motivasi dan Disiplin Kerja terhadap Kinerja Pegawai pada Badan Pengelola Pajak dan Restribusi Daerah Muaro Jambi

Tabel 7. t-test

\begin{tabular}{|c|c|c|c|c|c|c|}
\hline \multirow{2}{*}{\multicolumn{2}{|c|}{ Model }} & \multicolumn{2}{|c|}{ Unstandardized Coefficients } & Standardized Coefficients & \multirow[b]{2}{*}{$\mathrm{t}$} & \multirow[b]{2}{*}{ Sig. } \\
\hline & & $\mathrm{B}$ & Std. Error & Beta & & \\
\hline 1 & (Constant) & 8,266 & 3,766 & & 2,195 & ,033 \\
\hline & Motivasi & ,243 &, 118 & ,232 & 2,056 & ,045 \\
\hline & Disiplin &, 740 & 138 & 606 & 5,377 &, 000 \\
\hline
\end{tabular}

Berdasarkan Tabel 6 , maka dapat diketahui pengaruh masing-masing variabel sebagai berikut:Pengujian hipotesis secara parsial, Motivasi $\left(\mathrm{X}_{1}\right)$. Dari tabel nilai thitung $=2,056$ yang artinya thitung < ttabel $(2,056>1,678)$ dengan signifikan $0,045<0,05$ maka Ho ditolak dan Ha diterima. artinya secara parsial terdapat pengaruh signifikan antaraMotivasi(X1) terhadap Kinerja (Y).Pengujian hipotesis secara parsial, Disiplin $\left(\mathrm{X}_{2}\right)$. Dari tabel nilai thitung $=5,377$ yang artinya thitung $<$ ttabel $\quad(5,377<$ 1,678 ) dengan signifikan $0,000>0,05$ maka Ho ditolak dan $\mathrm{Ha}$ diterima. Artinya secara parsial terdapat pengaruh signifikan antara Disiplin terhadap Kinerja (Y).
Koefisien Korelasi dan Determinasi

Korelasi adalah suatu parameter untuk ukuran seberapa kuat atau erat antara variabel indenpenden dengan variabel dependen. Sedangkan koefisien determinasi $\left(\mathrm{R}^{2}\right)$ pada intinya mengukur seberapa jauh kemampuan model dalam menerangkan variabelvariabel dependen. Apabila $\mathrm{R}^{2}$ mendekati satu (1) maka dapat dikatakan semakin kuat model tersebut menerangkan variasi variabel independen terhadap variabel dependen. Sebaliknya jika $\mathrm{R}^{2}$ mendekati nol (0) maka semakin lemah variasi variabel independen menerangkan variabel-variabel dependen. Berdasarkan hasil output SPSS 22.00 besarnya nilai $r$ dan nilai $\mathrm{R}^{2}$ dapat dilihat pada tabel 8 sebagai berikut :

Tabel 8. Koefisien Korelasi dan Determinasi

\begin{tabular}{|c|c|c|c|c|}
\hline Model & $\mathrm{R}$ & R Square & Adjusted R Square & Std. Error of the Estimate \\
\hline 1 &, $837^{\mathrm{a}}$ & ,705 & ,680 & 3,44156 \\
\hline
\end{tabular}

Dari Tabel 4.20 hasil pengujian korelasi (r) yaitu sebesar 0,837 atau $83,7 \%$ yang berarti menunjukkan bahwa terjadi adanya hubungan yang sangat erat diantara variabel independen (Motivasi dan Disiplin) dengan variabel dependen (Kinerja). Dari tabel 4.20 juga dapat dilihat nilai Koefisien Determinasi $\left(\mathrm{R}^{2}\right)$ sebesar 0,705 atau $70,5 \%$ variasi Kinerja yang bisa dijelaskan oleh variasi dari variabel independen yaitu motivasi dan disiplin, sedangkan sisanya 29,5\% dijelaskan oleh faktor lain diluar penelitian.

\section{SIMPULAN}

Dari uraian pembahasan maka dapat disimpulan sebagai berikut :Bahwa hasil penelitian tentang pelaksanaan motivasi, disiplin dan kinerja pegawai pada Badan Pengelola Pajak dan Retribusi Daerah (BPPRD) Muaro Jambi, menunjukkan kategori baik. Dimana pada variabel motivasi skor rata-ratanya sebesar 191 kategori tinggi. Indikator pada variabel motivasi yang tertinggi adalah indikator ekstrinsik yakni sebesar 196 kategori tinggi. Dan pada variabel disiplin kerja dengan rata-rata skor sebesar 195 kategori tinggi. Dimana indikator yang tertinggi yakni mematuhi peraturan kantor sebesar 198 kategori tinggi. Dilain sisi variabel kinerja skor ratarata indikatornya sebesar 195 kategori baik. Dimana indikator sikap memiliki skor tertinggi yakni sebesar 203 kategori sangat baik. Dari model persamaan regresi linier berganda yakni : $\mathrm{Y}=8,266+0,243 \mathrm{X}_{1}+$ $0,740 \mathrm{X}_{2}+$ e. Bahwa variabel independen (motivasi dan disiplin kerja) secara simultan berpengaruh signifikan terhadap variabel dependen (kinerja anggota) pada Satuan Reserse Polresta Jambi. Dimana $F_{\text {hitung }}$ lebih besar dari $F_{\text {tabel }}$ yaitu $F_{\text {tabel }}$ atau $F_{\text {hitung }}>F_{\text {tabel }}$ $(16,014>3,20)$ dan nilai signifikansi yang lebih kecil dari $\alpha(0,05)$ yaitu ; $0,000<0,05$.

Secara parsial, variabel motivasi berpengaruh signifikan terhadap kinerja, dimana $t_{\text {hitung }}$ lebih besar dari $\mathrm{t}_{\text {tabel }}$ atau $\mathrm{t}_{\text {hitung }}>\mathrm{t}_{\text {tabel }}(2,056>1,678)$ dan prop.sig $<\alpha$ $(0,045<0,05)$. Selain itu variabel disiplin kerja berpengaruh signifikan terhadap kinerja, dimana $t_{\text {hitung }}$ lebih besar dari $t_{\text {tabel }}$ atau $t_{\text {hitung }}>t_{\text {tabel }}(5,377>2,678)$. Dan prop.sig $<\alpha(0,000<0,05)$.

\section{DAFTAR PUSTAKA}

Arikunto, Agus, 2010, Metodelogi Penelitian, Edisi Kelima, Graha Ganesha, Bandung.

Fuad, 2003, Analisis Manajemen, Gramedia, Jakarta

Handoko, T. Hani, 2005, Manajemen, PT. Ghalia Indonesia, Jakarta

Hasibuan, Malayu SP. 2012. Manajemen Sumber Daya Manusia. Penerbit Bumi Aksara. Jakarta

Husein, Umar 2013, Riset Sumber Daya Manusia, Gramedia Pustaka Utama, Jakarta

Istijanto . 2009. Aplikasi Riset. PT. Gramedia Pustaka Utama. Jakarta

Kaswan, 2012, Manajemen Sumber Daya Manusia Untuk Keunggulan Bersaing Organsiasi, Graha Ilmu, Yogyakarta

Kusumowidyo, 2001, Manajemen Personalia, BPFE UGM, Yogyakarta

Kurniawan, Albert, 2009, Belajar Mudah SPSS, PT. Buku Kita, Jakarta 
Mangkunegara, Anwar Prabu, 2008, Manajemen Sumber Daya Manusi, PT. Remaja Rosdakarya, Bandung

Rangkuti, Freddy, 2001, Pengantar Statistik, Penerbit Gramedia, Jakarta

Robbins, S. Stephen, 2008, Perilaku Organisasi, Edisi Kelima, Penerbit Salemba Empat, Jakarta

Samuelson, Paul, A, 2003, Pengantar Ilmu Ekonomi Mikro, PT. Media Global Edukasi , Jakarta

Sedarmayanti. 2009. Sumber Daya Manusia dan Produktivitas Kerja, CV. Mandar Maju. Bandung

Simamora, 2007, Manajemen Kepegawaian, Ghalia, Jakarta

Simanjuntak, Payaman, 2011, Manajemen dan Evaluasi Kinerja, FEUI, Jakarta

Siagian, 2009, Manajemen Sumberdaya Manusia Suatu Konsep, Edisi Kelima, PT Gramindo, Jakarta

Sunyoto, Danang, 2013, Teori, Kuesioner dan Analisis Data Sumber Daya Manusia, CAPS, Jakarta

Supardi, 2013, Aplikasi Statistika Dalam Penelitian, Change Publication, Jakarta

Sutrisno, Edy, 2011, Manajemen Sumber Daya Manusia, Kencana Prenada Media Group, Jakarta

Suwatno ,2011, Manajemen Sumber Daya Manusia, CV. Alfabeta, Bandung

Sugiyono 2010, Metodelogi Penelitian Kuantatif, Kuantatif dan $R \& D$, Liberty, Bandung.

Syekh, Sayid, 2011, Pengantar Statistik Ekonomi, Gaung Pesada Press, Jakarta

Veithzal, Rivai 2004, Kepemimpinan dan Perilaku Organisasi, PT.Rajagrafindo Persada, Jakarta

Wibowo, 2011, Perilaku Dalam Organisasi, PT. Rajagrafindo, Jakarta 